\title{
What Remains after Brexit? A View from the Outside
}

\author{
Filip Kokotovic \\ University College of International Relations and Diplomacy Dag \\ Hammarskjöld, Zagreb, Croatia \\ filip.kokotovic@hotmail.com \\ Dr Petar Kurecic \\ University North, Croatia \\ pkurecic@unin.hr
}

\begin{abstract}
The British referendum result to opt for exiting the European Union (EU) has left both the United Kingdom (UK), as well as the rest of the EU with questions regarding the future of the integration and their future economic development. While the $E U$ member-states present a united front in regards to the leave process, there are deeply rooted divisions on all other relevant policy questions. The issues of migration, foreign policy, and the level of cohesion within the EU itself represent the questions where there is little or no consensus. The paper concludes that both the UK and the EU need to address a deep political divide and find a way to coexist in the aftermath of Brexit.
\end{abstract}

Keywords: United Kingdom (UK), European Union (EU), Brexit, political implications, immigration

\section{Introduction}

Brexit was an event that shocked the political elite of the United Kingdom (UK), the leaders of the European Union (EU) and the EU bureaucracy. It shocked the Britons as well, no matter what option they supported - Remain or Leave. It also surprised, shocked, and/or scared many Europeans. It led to the immediate resignation of Prime Minister David Cameron, who firmly supported the Remain option, despite the fact that his government initiated the referendum. On the other hand, it led to the resignation of one of the most vigorous supporters of the Leave option, the UKIP leader Nigel Farage. With the implementation of Brexit, it would seem that UKIP has concluded its mission. It is currently struggling to find a niche where it might appeal to voters.

In the wake of the Brexit referendum both the EU and the UK face serious questions about the future. While the EU member-states present a united front in the leave process, there are deeply rooted divisions among them on other relevant policy questions. The issues of migration, foreign policy, and the level of cohesion within the EU itself are all questions where there is little or no consensus. The paper explores the factors that caused Brexit, the immediate economic implications for the UK, and the particular social implications for the EU. The UK strongly relies on exports as a source of revenue and generator of economic growth. It is therefore difficult to understand why the UK would risk trade with Europe by implementing a 'hard Brexit' that would 
leave the UK without the same level of access to the open market. On the other hand, migration inflow-an issue that is constantly at the forefront of the Brexit debate, seems to have a neutral or slightly positive impact on economic growth, as shown in our model later in this paper.

In explaining Brexit and why it occurred, we start with a detailed theoretical discussion. We review the national preference formation part of A. Moravcsik's (1993: 473-524) framework, as used in Jensen and Snaith (2016: 1302-1310). We proceed with the use of Prospect theory, which explains Brexit (and the Trump phenomenon as well) in terms of the groups of voters, so-called 'globalization losers' that have almost nothing to lose. These voters are therefore willing to take a risk for anti-establishment and untested political options. Then we turn to the factors that caused Brexit, the implications of Brexit for the EU, and public opinion in the EU member states. Finally, we address the immediate economic consequences of Brexit.

\section{Explaining Brexit: National Preference Formation theory and Prospect theory}

We believe three main developments, two long-term and one more recent, can be seen as the main factors that caused Brexit:

- the influx of EU and non-EU originated immigration into the UK, which has been ongoing for decades, but has increased rapidly since 2004;

- the neoliberalisation of British society, initiated under Thatcherism and impacting negatively on the accomplishments of Keynesian-style capitalism (the 'Golden Age' of capitalism) for more than three decades, including on the UK's manufacturing;

- the false and unrealisable promises of the Leave campaign that can be traced back to the period after (then) British Prime Minister Cameron in 2013 promised $^{1}$ the referendum on the UK's membership in the EU, to be held after the general elections in 2015. This factor is a product of the first two factors, combined with a risky political game played by former Prime Minister David Cameron. He believed that he would be able to control the level of resentment towards the EU and concurrently return the position of the Conservative Party, to that of the defender of the UK and national interests from the EU. Even at that time, his position had already been seriously questioned and jeopardized by the rise of the UK Independence Party (UKIP).

Each of the three afore-mentioned factors of Brexit will be further discussed in the following sections of this paper, before turning to the political and social consequences of Brexit that have already begun to impact not just on the UK, but on the EU as well.

The national preference formation part of Moravcsik's model for studying European integration (besides interstate bargaining, and choice of international institutions)

\footnotetext{
${ }^{1}$ The first occasion the UK's membership was put into question by the then leader of the opposition David Cameron was after the Lisbon Treaty was finally ratified by all member states, in November 2009. The Conservative Party and Mr Cameron led a campaign for a referendum on the Lisbon Treaty.

See: http://www.telegraph.co.uk/news/worldnews/europe/eu/6502361/EU-Lisbon-Treaty-David-Cameronpromises-vote-on-future-EU-changes.html (accessed May 20, 2017).

Then, in 2013, this time as Prime Minister, Mr Cameron promised a referendum on the membership of the UK in the EU: http://www.bbc.com/news/uk-politics-21148282 (accessed May 20, 2017).
} 
focuses on the process by which states form their objectives. It emphasizes the primacy of geopolitical factors and structures in the formation of national preferences. In the second theory of national preference formation, Moravcsik differentiates 'political economic' from 'economic' through the category of nation. While economic theories focus only on the consequences of policy for overall market efficiency, political economic theories take into account efficiency and distributional concerns, respectively. The relative strength of interest groups within a state is analysed, hence it determines how national preferences will be formed (see Moravcsik, 1993: 473-524).

Writing before Brexit actually occurred, Jensen and Snaith (2016: 1303) address three main elements of Moravcsik's framework, of which the second and the third ${ }^{2}$ element are of particular interest to us (Jensen and Snaith's premises are shown in regular typeface; comments and explanations of the author of this paper are in italics):

- Regarding the first element applied to Brexit and the UK: Gathering enough evidence that the membership in the EU benefits certain sectors of the UK economy (for example, agriculture i.e. farmers).

It has been argued that the media and public figures ignored important financial assessments and other quantifiable data regarding the UK's benefit from EU membership in arguing for 'Britain to go it alone's. This was a campaign of unrealistic and unrealisable promises as well as bombastic announcements, with most of the grievance projected towards the EU. The key question was not supposed to be whether the UK was benefitting from its membership in the EU, but who in Britain was really 'benefitting' and how much, and who was 'losing', and how much. The Remain campaign was not so cohesive. Mr. Cameron and Mr. Corbyn, who were supposed to be the main political opponents, both campaigned for the Remain option. The supporters of the Remain option were also overwhelmed by the power and persuasiveness of the Leave campaign supporters, which in the end turned out to be decisive.

- The second element applied to Brexit by Jensen and Snaith is: In the context of a potential Brexit, we should observe a change of interests or incentives - such as the decrease in economic interdependence - that would render it more favourable for the UK to go it alone.

We believe that a referendum on the UK membership, promised and organised by the UK government can be perceived as an expression of the tendency towards less interdependence and therefore less internationalisation. It is a negative reaction towards too much interdependence due to the UK's membership in the EU, although the possibility that the UK would ever join the EMU was nothing more than a fantasy.

- Moravcsik's third element, applied to Brexit by Jensen and Snaith, suggests that as the distributional consequences of policy co-ordination vary, opposition is to

\footnotetext{
2 The first element is based on a liberal understanding of state-society relations, according to which societal 'groups articulate preferences and governments aggregate them' (Moravcsik 1993: 482).

The second element predicts that vulnerability to externalities owing to economic interdependence creates incentives for governments to co-ordinate policies internationally (ibid: 485-486).

The third element suggests that as the distributional consequences of policy co-ordination vary, opposition is to be expected from those who are disadvantaged (ibid: 486-487).

3 ‘Brexit would damage Britain's economic growth prospects over the period 2016-2020. Exactly $68 \%$ of respondents thought that Brexit would increase the risk of a serious negative shock in British economy (Wielechowski and Czech, 2016: 177).'
} 
be expected from those who are disadvantaged This line of argumentation needs to be recalibrated, since the reference point is not future but rather existing international policy co-ordination, entailing that there must be either a change in the power equilibrium of domestic groups in favour or changes in their preferences.

This argument fits into the explanation that those who felt most disadvantaged (due to the neoliberalisation of British society, immigration that lowered the price of labour, the demise of UK manufacturing, and turning the City into the motor of the economy, with the majority of the benefits going to very few people) were the ones who made Brexit happen. The differences in socioeconomic status, age, and regional affiliations of the Leave and the Remain campaign supporters, offer us a picture of the Britain of haves and the Britain of have-nots.

The second theoretical framework that we address here is Prospect theory. This theoretical approach explains Brexit (and the Trump phenomenon as well) in terms of the groups of voters, so-called 'globalization losers' that have almost nothing to loseand who are therefore willing to take a risk. Prospect theory explains when and why people are willing to take risks. The key aspect it can explain is why so many people voted for Brexit (and Trump) despite knowing how much uncertainty the outcome of their vote, if successful, would bring. By giving examples from the game of roulette, Heintz (2016) explains in what situations Prospect theory identifies people as risk seeking or risk averse and points out that in situations when people have little to lose, they are more willing to take risks. Brexit and Trump campaigns have been focused more on the losses than on gains, and their key messages 'Taking back control' and 'Make America great again', respectively, as Heintz emphasized, have referred to the lost grandeur of the past. Brexit and Trump voters are mostly those people who feel they have lost something, and are willing to take risks to try to overcome their economic frustrations.

\section{The Factors that Caused Brexit \#1: Immigration to the United Kingdom}

Among the factors that influenced the decision of the majority of UK voters, Sinn (2016: 42) points out immigration from other EU countries, fears of an obligation to 'save' Southern Europe, and a sense that the UK's citizens have become alienated from its political class because of the supranational aspects that come with being part of the EU.

Gietel-Basten (2016: 674) pointed out that in the second half of the 200os, net migration to the UK fluctuated between three and four hundred thousand per year, reaching a peak just before the onset of the 2008 financial crisis (ONS, 2016). Britain had been one of only a few EU member states not to impose any restrictions on free movement following 2004, the year of the largest ever EU enlargement (see VargasSilva, 2016: 251-255). Nevertheless, it remains unclear whether immigration was the most important factor. The areas where immigrants have settled mostly did not show high level of support for the UKIP ${ }^{4}$.

\footnotetext{
4 http://www.telegraph.co.uk/news/politics/ukip/11539388/Mapped-where-is-Ukips-support-strongest-Wherethere-are-no-immigrants.html (accessed May 20, 2017).
} 
The analysis of migration as a driving force for Brexit requires a quantitative analysis which would study the effects of migration on the UK's economy. A regressive model is included that gradually increases the number of variables, with observations for annual data for the period 1975-2012. This serves two purposes - increasing the predictability value of the model, and, as net migration will serve as one of the 'basic' variables, it is possible to determine whether or not the impact of net migration on economic growth at some stage became negative for the economy of the UK. To clarify, this regressive model is based on a standard Ordinary Least Squares (OLS) regression, where the impact of a series of variables, such as inflation (CPI index), life expectancy, export revenue, tax revenue, net migration, and the interest rate on the economic growth were measured through the value of the UK's GDP.

Log transformations are required for the following variables: export revenue, tax revenue, net migration, as well as GDP, in order to avoid errors concerning heteroscedasticity. Data concerning net migration was extracted from Migration Watch (2017), while the remaining variables were extracted from the UK Office for National Statistics (2017). In order to avoid errors concerning 'spurious' or statistically insignificant regression models, the Augmented Dickey Fuller (ADF) test was used to determine whether the variables are stationary. If the variable was not stationary, the difference of the variable was calculated and the variable was used in the difference in which we find that variable is stationary. The number of lags used was automatically determined based on the Akaike information criterion. The summary of the test results, as well as the information on the transformations on the variables is presented in Table 1.

Table 1: Augmented Dickey Fuller (ADF) test

\begin{tabular}{|c|c|c|}
\hline Variable & Conclusion & $\begin{array}{c}\text { Transformation } \\
\text { performed }\end{array}$ \\
\hline Export & $\mathrm{I}(1)$ & Log difference \\
\hline Life exp & $\mathrm{I}(1)$ & First difference \\
\hline Interest rate & $\mathrm{I}(0)$ & In original form \\
\hline CPI & $\mathrm{I}(0)$ & In original form \\
\hline Tax revenue & $\mathrm{I}(1)$ & Log difference \\
\hline GDP & $\mathrm{I}(1)$ & Log transformation \\
\hline Net migration & $\mathrm{I}(0)$ & \\
\hline
\end{tabular}

Source: Authors' calculations and GRETLE output

In order to estimate the regression model, we will start with a basic model that estimates the impact of exports and migration on GDP, while including a constant and error term. The regression will then further include the additional variables, as presented in Table 1 . The results of the regression coefficients are presented in Table 2.

Table 2: The summary of regression models used

\begin{tabular}{|l|c|c|c|c|c|c|c|c|}
\hline & F-statistic & $\begin{array}{c}\text { R- } \\
\text { squared }\end{array}$ & Export & Migration & Lifeexp & $\begin{array}{c}\text { Tax } \\
\text { revenue }\end{array}$ & $\begin{array}{c}\text { CPI } \\
\text { Interest } \\
\text { rate }\end{array}$ \\
\hline
\end{tabular}




\begin{tabular}{|c|c|c|c|c|c|c|c|c|}
\hline $\begin{array}{c}\text { Model } \\
1\end{array}$ & $\begin{array}{l}9.383 * * \\
(0.0006)\end{array}$ & 0.3557 & $\begin{array}{l}0.294 * * \\
(0.004)\end{array}$ & $\begin{array}{c}0.015 \\
(0.2769)\end{array}$ & & & & \\
\hline $\begin{array}{c}\text { Model } \\
2\end{array}$ & $\begin{array}{l}6.6319^{* *} \\
(0.0012)\end{array}$ & 0.3761 & $\begin{array}{c}0.2901 * * \\
(0.005)\end{array}$ & $\begin{array}{c}0.0012 \\
(0.4181)\end{array}$ & $\begin{array}{l}-0.0181 \\
(0.3055)\end{array}$ & & & \\
\hline $\begin{array}{c}\text { Model } \\
3\end{array}$ & $\begin{array}{c}5.825^{*} \\
(0.0012)\end{array}$ & 0.4213 & $\begin{array}{l}0.2645^{*} \\
(0.013)\end{array}$ & $\begin{array}{l}0.00124 \\
(0.3846)\end{array}$ & $\begin{array}{c}-0.017 \\
(0.3205)\end{array}$ & $\begin{array}{c}0.0402 \\
(0.1236)\end{array}$ & & \\
\hline $\begin{array}{c}\text { Model } \\
4\end{array}$ & $\begin{array}{l}6.839 * * \\
(0.0002)\end{array}$ & 0.5245 & $\begin{array}{c}0.2563 * * \\
(0.0008)\end{array}$ & $\begin{array}{c}0.0007 \\
(0.6133)\end{array}$ & $\begin{array}{c}-0.023 \\
(0.1612)\end{array}$ & $\begin{array}{l}0.0588^{*} \\
(0.023)\end{array}$ & $\begin{array}{l}-0.02 * \\
(0.014)\end{array}$ & \\
\hline $\begin{array}{c}\text { Model } \\
5\end{array}$ & $\begin{array}{c}9.3413 * * \\
(0.0000)\end{array}$ & 0.6514 & $\begin{array}{l}0.222 * * \\
(0.001)\end{array}$ & $\begin{array}{c}0.0014 \\
(0.2722)\end{array}$ & $\begin{array}{l}-0.0156 \\
(0.2722)\end{array}$ & $\begin{array}{l}0.052 * \\
(0.021)\end{array}$ & $\begin{array}{c}-0.034 * * \\
(0.0001)\end{array}$ & $\begin{array}{l}0.0036^{*} \\
(0.025)\end{array}$ \\
\hline
\end{tabular}

Source: Authors' calculations and GRETLE output

Note: values in the parenthesis represent the p value, while * and ${ }^{* *}$ indicate statistical significance at the 0.05 and 0.01 levels of statistical significance respectively.

These regressive models have proven several aspects of what was encompassed in the theoretical discussion i.e. qualitative analysis of this paper. Migration inflow, an issue constantly at the forefront of the Brexit debate, seems to have a neutral or slightly positive impact on the UK's economic growth; hence there are no negative values of correlation in the Migration column. It is not possible to determine any evidence of a negative impact of the increase of migration on economic growth.

\section{The Factors that Caused Brexit \# 2 \& \#3: The Neoliberalisation of British Society and the Promises of the Leave Campaign}

The continuing, persistent neoliberalisation of British society, whose beginnings can be traced to the Thatcher era, has had a strong impact on the society of the UK. Especially in England, society became more divided, by age, education, regional affiliation, and sectors of economic activity. The Labour governments of Prime Ministers T. Blair and G. Brown kept most of the Thatcher era policies. The impact of these policies has found its reflection in many aspects of social life, such as attempts to control labour beyond the work place by attacking the position of trade unions combined with aspects of social conservatism attacking the gains made by minority groups such as women, gay and ethnic groups in the 1960s and 1970s (Harvey, 2005).

The results of the divisions in British society are reflected in the results of the vote on Brexit, by regional affiliation, age, education, and the background of the voters. The groups that supported Brexit the most were elderly, blue-collar working or retired people, mostly living in Northern and Central England, and completely untouched (except in a negative context) by the financialisation and globalisation of Southern England - London and the City ${ }^{5}$ in particular.

Desai and Freeman (2016: 15) have noted that Britain's Gini coefficient, the measure of its inequality, has risen from about 0.26 in 1979 to over 0.4 today. The authors have pointed out that neoliberalism has divided Britain geographically, into a prosperous London and South East, an especially depressed North with its deindustrialised run-

\footnotetext{
${ }^{5}$ The very differing experiences of London and its hinterland from the rest of the UK are a result of the fact that the London economy has responded to modern globalisation since the late $1980 \mathrm{os}$ in a totally different manner than other parts of the UK (Los et al., 2017: 5).
} 
down cities, and a mildly more social democratic Scotland able to avoid some of the worst of the social breakdown visited upon the north of England, with the rest of the country performing indifferently.

Clarke and Newman (2017: 107) have identified three groups that have been offered to the British voters by the Leave campaign as responsible for the present situation. These groups are: the metropolitan-cosmopolitan liberal elite (out of touch Europhiles, the architects of political correctness, insulated by wealth and social position from the effects of Europeanisation); the European elite (i.e. German Chancellor Merkel and the EU bureaucrats), and the migrants, enabled by Europe's free movement rules and consuming scarce resources, with the claim (only partially correct) that the UK's membership in the EU is the main factor that lures the migrants to the UK (Clarke and Neman, 2017).

Looking at Brexit from an Australian perspective, Quiggin (2016: 567-568) argues that it has been a major failure of the left in not articulating a viable alternative to neoliberalism. He explains that the conventional wisdom has been that a weakening of globalisation would undermine Australian living standards. However, major issues remain, as Quiggin points out - reducing inequality, but without resorting to protectionism.

The dictatorship of neoliberal capitalism and the 'TINA' (There Is No Alternative)6 doctrine, continues, despite the Great Recession (actually the recession activated the Keynesianism mechanisms of saving the irresponsible, often predatory private capital, concentrated in the financial sector, and therefore endorsed further neoliberalisation of capitalist economies). In that sense, Brexit can be perceived as a reaction of 'the globalisation/neoliberalisation losers'.

The (false) promises that the exit from the EU will allow Britain to take back full control over its destiny, to restrict migration, to disregard Brussels bureaucrats and to regain its colonial time influence were among the biggest promises of the Leave campaign ${ }^{7}$. The protection of the NHS system of health security ${ }^{8}$ and the promise that 350 million pounds per week would be injected into the NHS instead of sending them to 'Brussels' was probably the promise that was decisive among the middle-aged and elderly, bluecollar population of Northern and Central England, whose pro-Brexit stance in the end prevailed. Such a claim was even disavowed by Prime Minister, Theresa May, although she never promised it, and therefore is not responsible. On the other hand, Boris Johnson, who was part of the Leave campaign, and was making such promises is one of the key members of the both UK governments determined to extract the UK from the EU through means of a 'hard Brexit'" . The fact that both May governments consist

\footnotetext{
${ }^{6}$ A phrase/doctrine of neoliberal proponents of the omnipresent globalization, first used in the 1980 s by M. Thatcher, and used again by D. Cameron: 'If there was another way I would take it. But there is no alternative.' http://www.bbc.com/news/uk-politics-21703018; http://www.pandopopulus.com/tina-there-is-no-alternative/ (accessed May 20, 2017).

7 'Many protest voters have made it clear that they are protesting the failure of the 'establishment' to address the problems of workers and communities left behind by a shift out of primary and secondary industries and by automation-in effect by globalisation. It is not clear how decoupling from the EU will make that better (Watts, 2017: 102).'

8 'Brexit was about gut-wrenching issues like borders, culture, and the homeland. Remarkable to many outsiders, the NHS is almost a religion in the UK; its 'overstretching'-especially by foreigners-presented as a blasphemy (Gietel-Basten, 2016: 678).'

${ }^{9}$ http://www.mirror.co.uk/news/politics/theresa-admits-350-million-pledged-10124021 (accessed May 20, 2017).
} 
of Brexiteers and Remain supporters points to the lack of credibility of the government(s) to pursue a 'hard Brexit', with the modifying stance of the Labour party, significantly more represented in the Parliament after the recent general elections on 8 June 2017, not quite supporting the proclaimed goal: 'Brexit means Brexit'.

Discussing the issues that were used in pro and contra Brexit campaign(s), Das (2016: 18) pointed out that the debate was always between economics and sovereignty (in the guise of immigration and border control), with exaggerated claims of economic losses, based on macro-economic models, which have failed to engender fear, rejected. Sovereignty, no matter how it was imagined and presented, prevailed. Additionally what seems to be a backfire syndrome and the confirmation of Prospect theory, some of the UK regions reliant on exports to the EU voted strongly to leave that same EU.

The groups in the British society who felt left behind by globalisation, financialisation, the City, and Brussels, were the ones that made 'their voice heard', their expectations fuelled by the promises of 'taking back control'. Something similar happened in November 2016 in the U.S.A., with the election of Trump for president. The key for winning the support in the 'battleground states' was speaking as the voice of the same forgotten, blue-collar workers, whose position in the society was declining.

\section{The Implications of Brexit on the EU and the Public Opinion in the EU Member States}

Brexit is turning out to be a rising problem for the UK. The growth of the problem is incremental, as the day of a planned 'divorce' with the EU approaches, and initial positions still have not been assumed. The position of the old-new government in Westminster reflects the unrealistic promises made during the campaign that it is possible to leave the EU, without bearing the additional costs and being able to keep maximum benefits, and not bear the responsibilities and the burden of payment in case the UK wants to remain a part of the EU's single market. It seems that Westminster wants to pick what it wants from the EU, and what it does not, similar to the way the UK has always behaved in its relations with Europe and the EU - always keeping its special relations with the U.S.A. and its special position towards the 'Continent'. Two French vetoes before the UK actually was able to join the (then) European Community (EC), a referendum on the UK membership in the EC only two years after its accession (held in 1975), the UK's decision not to even consider accepting the Euro, are some indicators of the UK position. The UK's negotiating position on the terms of Brexit grows weaker with the passage of time, and the new government is weaker than the old. It has lost the support of the Labour party for its Brexit plans, which the first May government initially had.

There is a view, shared by Dennison et al. (2016: 4), that the UK will still be one of the most important states in the world - fifth largest economy, one of the most powerful NATO member states, and the leader of the Commonwealth, championing free trade, now unburdened by unnecessary EU rules and regulations. However, the authors also emphasised that Brexiteers failed to point to any foreign policy areas where Britain has actually been held back by the EU. De Grauwe (2016: 250) warned that the choice for the UK will be difficult. Either the UK government will embrace (a close version of) the Norwegian model or it will need to stand alone and negotiate new trade agreements with the EU and about 50 other countries (or group of countries) within the framework of the rules of the World Trade Organization (WTO). 
As every issue has two sides - while Brexit represents a major issue for the UK, it also poses one of the key issues for the EU as a whole, its functioning and unity. Brexit can be interpreted as the most important sign from the demos in one of the (still) EU member states that the EU as such needs a thorough overhaul. Otherwise, the EU faces the danger of becoming (even) more dysfunctional, with rancour felt by significant parts of the demos in the increasing number of its member state sat a time of terrorist attacks, rising xenophobia, continuous non-EU irregular migrant influx, with the member states sharing the burden ever more disproportionately, not to mention an aggressive Russia and an aggrieved Turkey, with imperial visions of their strong leaders, respectively.

Brexit also adversely affects the EU in economic, political, social and financial aspects. The effects of Brexit include decreasing political and military power of the EU (the UK spent USD 57 billion, i.e. 2.4\% GDP on military purposes in 2013); reduction of demographic potential of the EU (by 65 million, i.e. 12.8\%); reducing economic potential of the EU (reduction of GDP by $17.5 \%$, reduction of merchandise exports by $23 \%$ and reduction of commercial services exports by almost 38\%); reducing the EU budget (as a result of Brexit the EU will lose an important net contributor: in 2015 the UK paid GBP 13 billion to the EU budget and received GBP 4.5 billion (Pawlas, 2017: 69-70).

Sutherland (2016: 312) pointed out that the chaos after the Brexit vote has had one positive effect, namely increased support for the EU in the remaining EU27, and only may prove to be less in (post-communist, authors' remark) Central and Eastern Europe, where politics is showing a strong nationalist tendency.

Poli (2016: 4) noted that in Germany and Belgium the citizens mostly did not understand why the Britons chose to opt-out of the EU. The Italians and French appeared to be more sympathetic towards the British decision to leave the EU. This might certainly be explained by anti-EU sentiments registered in those countries over the previous few years ${ }^{10}$.'

\footnotetext{
${ }^{10}$ The pattern seems clear - the citizens of the countries that have more economic problems and feel that the EMU is not bringing those enough benefits were more sympathetic to Brexit. More in: Poli, 2016: 6.
} 


\section{The Immediate Economic Implications of Brexit on the UK}

Before the referendum on Brexit took place, various prognoses assessed the possible negative impacts on the UK economy. Marshall (2016: 455) stated that after Brexit, the UK's economic power has dropped immediately, with France overtaking the UK and becoming the fourth largest economy of the world (and the second largest economy of the EU). Marshall also warned about the vulnerability of the UK's economy, emphasising the negative balance of payments in the last 30 years, rising deficit (as \% of GDP), and a short term (which actually turns out to look like mid-term) sharp decrease of the sterling exchange rate. Sinn (2016: 43) emphasized the post-Brexit problems for the financial sector, emphasising that the joint British-German stock exchange will hardly be able to set up its main headquarters in London now, and estimating, probably too pessimistically, that London real-estate prices will fall, and financial institutes will go bankrupt. Desai and Freeman (2016: 13) emphasised the negative financial consequences of Brexit; hence it may have caused stock markets to take their deepest plunge ever, sending the pound sterling down to a 31-year low.

Predicting the outcomes of Brexit regarding financial matters, Mendez-Parra et al. ${ }^{11}$ have predicted Brexit could cause a $10 \%$ devaluation of the pound, and a possible reduction in UK's GDP of $3 \%$, as well as decline in British exports to developing countries. Additionally, Beck (2016: 26) warned about the importance of the FDI and the connections between the UK and the EU, pointing out that almost half of FDI in the UK comes from other EU countries, which suggests that EU membership is not the only driver of foreign investment in the UK. However, these deepening and increasingly complex relationships arereflected by the fact that half of the UK's inward stocks of foreign investment and also half the UK's outward foreign investment stocks are with the EU, which is shown in the data provided by Allen and Dar (2013: 4).

Less than a year after Brexit, there are five signs that it is hurting the UK economy: inflation is on the rise, GDP growth is decreasing, immigration is slowing down, house prices are slumping, and mortgage lending is falling ${ }^{12}$.

\section{Conclusion}

Brexit was an unexpected, abrupt event, in which certain groups in UK society, as well as certain regions, overwhelmingly voted for leaving the EU, thereby critically influencing the outcome. Neither the majority of the UK political elite nor the political elites of the EU member states wanted Brexit to happen. However, when it happened, after the initial shock, a sense of relief and acceptance of the new reality has spread. Brexit has shown divisions in UK society, regional, divisions by age and level of education. Brexit is primarily a consequence of neoliberalisation of British society and the rising social inequalities it has caused, of immigration to the UK, and of the false promises made by the Leave campaigners. It has brought significant negative effects to the UK economy, and jeopardized the position of the UK citizens working and living in EU countries, and vice versa. The long-term effects will be more negative for the UK than for the post-Brexit EU27.

\footnotetext{
${ }^{11}$ https://www.odi.org/publications/10480-brexit-and-development-how-will-developing-countries-be-affected (accessed May 20, 2017).

${ }^{12} \mathrm{http}$ ://www.independent.co.uk/news/business/news/brexit-latest-news-signs-uk-economy-hurt-leave-euinflation-pound-sterling-jobs-lending-bank-of-a7767526.html (accessed May 20, 2017).
} 


\section{References}

Allen, G. and A. Dar, 'Foreign direct investment (SN/EP/1828)', Economic Policy and Statistics, House of Commons Library, London, 2013.

Barrett, G., 'Theresa May has two clear options on Brexit-neither of them easy', EUROPP (European Politics and Policy) Blog, London School of Economics and Political Science, 12 July 2016, http://bit.ly/29CILST (accessed July 14, 2017).

Beck, M., 'Brexit and FDI', in: Assessing the Economic Implications of Brexit. Oxford Economics Research Program, 2016, pp. 26-30, http://www.oxfordeconomics.com/brexit (accessed October 10, 2016).

Clarke, J. and J. Newman, 'People in this country have had enough of experts': Brexit and the paradoxes of populism', Critical Policy Studies, Vol. 11, No. 1, 2017, pp. 101116.

Das, S., 'What Will History Make of Brexit?', Wilmott Magazine, 2016, pp. 16-18.

Dennison, S., M. Leonard and N. Witney, 'One Hundred Years of British Solitude: Magical Thinking about Brexit and Security', European Council on Foreign Relations Essay, Vol. 17, No. 3, 2016, pp. 1-6.

Desai, R. and A. Freeman, 'Brexit, the City and the Crisis of Conservatism', Valdai Discussion Club Report, 2016, pp. 1-19.

Dodds, L. and R. Akkoc, 'Mapped: Where is UKIP's support strongest? Where there are no immigrants', The Telegraph, 17 April 2015, http://www.telegraph.co.uk/news/politics/ukip/11539388/Mapped-where-is-Ukipssupport-strongest-Where-there-are-no-immigrants.html (accessed May 27, 2017).

Gietel-Basten, S., 'Why Brexit? The Toxic Mix of Immigration and Austerity', Population and Development Review, Vol. 42, No. 4, 2016, pp. 673-680.

de Grauwe, P., 'What Future for the EU after Brexit?', Intereconomics - Review of European Economic Policy, Vol. 51, No. 5, 2016, pp. 249-251.

Harvey, D., A Brief History of Neoliberalism, Oxford: Oxford University Press, 2005.

Heintz, C., 'Does Prospect theory explain Trump and Brexit votes?', International Cognition and Culture, November 15, 2016, http://cognitionandculture.net/blog/christophe-heintzs-blog/does-prospect-theoryexplain-trump-and-brexit-votes (accessed August 30, 2017).

Jensen, M.D. and H. Snaith, 'When politics prevails: the political economy of a Brexit', Journal of European Public Policy, Vol. 23, No. 9, 2016, pp. 1302-1310.

Marshall, P., 'Brexit in its Worldwide Aspect: An Opportunity to be Grasped', The Round Table: The Commonwealth Journal of International Affairs, Vol. 105, No. 5, 2016, pp. 451-461. 
Mendez-Parra, M., P. Papadavid and D. te Velde, 'Brexit and development: How will developing countries be affected?' Overseas Development Institute Briefing, July 2016, https://www.odi.org/publications/10480-brexit-and-development-how-willdeveloping-countries-be-affected (accessed February 21, 2017).

Moravcsik, A., 'Preferences and power in the European Community: a liberal intergovernmentalist approach', JCMS: Journal of Common Market Studies, Vol. 31, 1993, pp. 473-524.

Moravcsik, A., 'The Choice for Europe: Social Purpose and State Power from Rome to Maastricht', Ithaca, NY: Cornell University Press, 1998.

Pawlas, I., 'Brexit as a Challenge for the European Union', Horyzonty Polityki, Vol. 20, 2017, pp. 57-76.

Poli, E., 'Mapping Member States' Stances in a Post-Brexit European Union', IAI Working Papers, Vol. 16, No. 31, 2016, pp. 1-18.

Quiggin, J., 'Reaping the Whirlwind: Inside Story', 26 June 2016, http://insidestory.org.au/reaping-the-whirlwind (accessed 15 July 2017).

Sinn, H.-W., 'A Brexit Lesson: Is a Single Currency Not Worth the Gamble?' The International Economy, summer issue, 2016, pp. 42-70.

Sutherland, P. D., 'Brexit: What Does It Mean For Europe?' Studies, Vol. 105, No. 419, 2016, pp. 309-318.

Vargas-Silva, C., 'EU migration to and from the UK', Intereconomics - Review of European Economic Policy, Vol. 51, No. 5, 2016, pp. 251-255.

Watts, N., 'Brexit: Unintended and Unanticipated Consequences', The Round Table, Vol. 106, No. 1, 2017, pp.101-103.

Wielechowski, M. and K. Czech, 'Brexit Related Uncertainty for United Kingdom Economy' Oeconomia, Vol. 15, No. 4, 2016, pp. 171-181.

\section{Websites}

Migration Watch, 2017, https://www.migrationwatchuk.org/statistics-net-migrationstatistics (accessed May 25, 2017).

UK Office for National Statistics, 2017, https://www.ons.gov.uk/ (accessed May 25, 2017).

http://www.mirror.co.uk/news/politics/theresa-admits-350-million-pledged10124021 (accessed May 8, 2017).

http://www.telegraph.co.uk/news/worldnews/europe/eu/6502361/EU-LisbonTreaty-David-Cameron-promises-vote-on-future-EU-changes.html (accessed May 8, 2017).

http://www.bbc.com/news/uk-politics-21148282 (accessed May 8, 2017). 
http://www.independent.co.uk/news/business/news/brexit-latest-news-signs-ukeconomy-hurt-leave-eu-inflation-pound-sterling-jobs-lending-bank-ofa7767526.html (accessed June 8, 2017).

http://www.bbc.com/news/uk-politics-21703018 (accessed May 20, 2017).

http://www.pandopopulus.com/tina-there-is-no-alternative/ (accessed May 20, 2017). 